\title{
KONSEP EKONOMI ISLAM JALAN TENGAH (KAPITALIS - SOSIALIS)
}

\author{
Muhammad Tho'in \\ Prodi Ekonomi Islam, STIE-AAS Surakarta \\ Email: thoinsyakira@yahoo.com
}

\begin{abstract}
This study aimed to explore how the actual concept of Islamic economics as a middle way that stands between a socialist economic system and the capitalist economic system, as well as whether the greatest challenge of Islamic economics. Type of the research is a qualitative research method, literature.

The results obtained by the capitalist system and the socialist economic system have not able to realize prosperity and justice for both individuals as part of the state (socialist economic system) and the public at large or the workers (the capitalist economic system). So inevitably need for a breakthrough by developing the concept of an Islamic economic system msebagai middle way by combining two forms of the previous economic system, the capitalist economic system and the economic system of socialism. This unification effort is made to take the positive side and the dynamic of the two. Meanwhile, the great challenge of Islamic economics is faced with two things, namely poverty and ignorance.
\end{abstract}

Keywords: Concepts, Islamic Economics, Middle Way

\section{Pendahuluan}

Sistem perkonomian merupakan sebuah skema yang digunakan suatu negara tertentu di dalam memecahkan persoalan-persoalan ekonomi yang dialami oleh negara tersebut, agar persoalan ekonomi itu dapat teratasi, jangan sampai dengan adanya sistem ekonomi justru menambah masalah atau persoalan ekonomi suatu negara, walaupun jika ditinjau, sampai saat ini belum ada sistem ekonomi yang sempurna yang mampu menyelesaikan persoalan bangsa khususnya dalam hal keadilan dan pemerataan bagi masyarakatnya yang ada. Secara garis besar sistem ekonomi di dunia didominasi oleh dua sistem, yaitu sistem ekonomi kapitalis dan sistem ekonomi sosialis. Sistem ekonomi kapitalis bersandar kepada pemilikan pribadi maupun swasta terhadap alat-alat produksi, kegiatan distribusi, maupun pertukaran. Sehingga tiga hal utama tersebut berada penuh di tangan swasta. Sistem ekonomi kapitalis mendominasi secara keseluruhan dari sistem ekonomi yang dianut oleh negara-negara di dunia. Dimana, di dalam sistem ekonomi kapitalis ini, suatu produksi maupun perdagangannya lebih dominan dilakukan bersifat individualistis atau pribadi. Individu serta perusahaan atau bahkan melalui badan usaha swasta atau korporasi, berupa bantuan modal yang sebelumnya telah diakumulasikan, tetapi yang lebih banyak terjadi dengan menggunakan modal usaha dari pinjaman berbunga, mendapatkan keuntungan atau laba serta membangun suatu kerajaan 
untuk diri mereka sendiri dengan jalan mempekerjakan orang banyak dengan memberikan imbalan upah (Chaudhry, 2012: 355-356)

Sedangkan sistem ekonomi yang kedua, adalah sistem ekonomi sosialis. Sistem ini berkebalikan dengan sistem ekonomi kapitalis. Dimana, di dalam sistem ekonomi ini kegiatan-kegiatan ekonominya mulai dari perencanaan, pelaksanaan, serta pengawasan dilakukan oleh pemerintah secara terpusat. Sehingga setiap individu tidak berhak atas kekayaan yang dimilikinya, karena alat-alat produksi, kegiatan distribusi, maupun pertukaran dilakukan oleh pemerintah dengan tujuan kesejahteraan masyarakat bersama.

Kedua sistem ekonomi tersebut tentunya memiliki kelebihan dan kekurangan masingmasing. Hal yang paling mendasar dari kedua sistem ini adalah masih adanya aspek kedholiman. Pada sistem ekonomi kapitalis, masyarakat kecil selaku buruh mendapatkan perlakukan semena-mena dari pemilik modal, terutama kebijakan upah dan lain sebagainya. Sedangkan pada sistem ekonomi sosialis, hakhak individu yang seharusnya dapat ia miliki tidak diperbolehkan oleh pemerintah. Hal tersebut mendorong untuk terwujudnya konsep sistem ekonomi yang baru (di antara kapitalis dan sosialis). Sehingga para pemilik modal tetap dapat menjalankan usahanya tanpa merugikan buruh maupun orang lain, dan kepemilikan kekayaan pribadi tetap diakui dalam batas-batas yang ditentukan.

Dengan demikian, adanya ekonomi Islam diharapkan dapat menjadi solusi dari permasalahan yang ada, sebagai sistem ekonomi jalan tengah. Sehingga, harapan terwujudnya sistem ekonomi yang berkeadilan menuju kemakmuran dan pemerataan "baldatun thayyibatun wa rabbun ghafur" dapat tercipta.

Penelitian ini akan mencoba mencari konsep ekonomi jalan tengah, dalam hal ini yaitu konsep sistem ekonomi Islam sebagai jalan tengah yang berdiri diantara sistem ekonomi kapitalis dan sistem ekonomi sosialis dengan melihat kebaikan dan kelemahan dari masing-masing sistem tersebut, kemudian kebaikan-kebaikan kedua sistem ekonomi tersebut (kapitalis dan sosialis) dipadukan dan digunakan sebagai konsep ekonomi Islam selama kebaikan tersebut sejalan pula dengan ketentuan-ketentuan syariah Islam, serta mencari tantangan yang menjadi hambatan dari ekonomi Islam itu sendiri.

\section{Sistem Ekonomi Kapitalis}

Sistem ekonomi kapitalis menjadi sistem ekonomi yang mendominasi dari sistem ekonomi yang dipakai negara-negara saat ini. Meskipun dengan perkembangan teknologi dan informasi atau IT yang begitu dahsyat saat ini, boleh dikatakan tidak ada sistem ekonomi kapitalis murni, karena di negara-negara 
kapitalis lebih sosialis dibandingkan dengan negara-negara yang menggunakan sistem ekonomi sosialis itu sendiri. (Asy'arie, Disampaikan dalam Focused Group Discussion Matakuliah Sejarah Pemikiran Ekonomi Islam, Pascasarjana UIN Sunan Kalijaga, Kamis, 15 Desember 2016)

Menurut Winardi (1990) Sistem ekonomi kapitalis ini, merupakan suatu sistem ekonomi di mana hak milik pribadi atas alatalat produksi, kegiatan distribusi, serta pemanfaatannya untuk mencapai laba dalam kondisi maupun situasi yang sangat kompetitif, menjadi ciri utama dalam sistem ini. Jika kita melihat sejarah, kapitalisme dibangun dari buah pemikiran tokoh ekonomi besar yaitu Adam Smith, dia merupakan tokoh dari mazhab klasik.

Para ahli ekonomi dunia mayoritas sepakat bahwa hasil dari pemikiran mazhab klasik inilah yang menjadi dasar dari sistim ekonomi, yaitu sistem ekonomi kapitalis (Agustiati, 2009: 152). Dasar pemikiran teori yang dikeluarkan oleh Adam Smith ini dapat bertahan hingga terjadinya depressi ekonomi pada tahun 1929, di mana pada saat itu pemikir ekonomi lainnya, yaitu Keyness mengeluarkan gagasannya, dia tampil serta berhasil mengungkapkan sebuah teori dan gagasan bahwa sistem ekonomi yang baru dan lebih baik dapat dibangun. Pemikiran Keyness ini atau Keynesian membutuhkan adanya intervensi serta campur tangan dari pemerintah dalam menentukan kebijakan-kebijakan ekonomi. Hal inilah yang menjadi awal jatuhnya sistem ekonomi kapitalis saat itu, akan tetapi dengan berjalan waktu selama lebih kurang 30 tahun terjadi krisis yang besar yang melanda dunia, berupa krisis minyak dunia tepatnya pada tahun 1973, sistem ekonomi kapitalis yang jatuh kembali tampil sebagai sistem ekonomi dengan nama baru, yaitu neoliberalisme (Agustiati, 2009: 152).

1. Pilar-pilar sistem ekonomi kapitalis

Sistem ekonomi kapitalis ini menyadarkan diri secara penuh kepada hal-hal di bawah ini:

a. Private property atau hak milik swasta

b. The invisibel hand atau dibina oleh tangan tak terlihat

c. Idividualisme ekonomi

d. Free market kompetition atau persaingan dan pasar bebas

2. Kerangka dasar sistem ekonomi kapitalis

a. Kelangkaan sumber-sumber ekonomi

Benturan antara kebutuhan manusia yang tidak terbatas dengan terbatasnya (langkanya) barang-barang ekonomi yang tersedia dalam usaha menjembatani hal tersebut adalah dengan jalan menambah jumlah produksi barang dan jasa sebanyakbanyaknya agar kebutuhan manusia yang tidak terbatas dapat diperkecil, adanya kelangkan sumber-sumber ekonomi maka para ekonomi kapitalis 
melihat 3 pokok permasalahan ekonomi yang harus dipecahkan (1) Apa yang harus diproduksi dan dalam jumlah berapa? pertanyaan pertama ini secara umum menyangkut barang dan jasa yang dibutuhkan manusia, dan secara khusus menyangkut singkronisasi antara kebutuhan manusia dengan daya belinya. (2) Bagaimana sumber-sumber ekonomi (faktor-faktor produksi) yang tersedia harus dipergunakan untuk memproduksi barang-barang tersebut? jawaban permasalahan yang kedua ini adalah menyangkut tentang teknik produksi, yaitu bagaimana mengkombinasikan faktor-faktor produksi untuk mendapatkan output yang optimal. (3) Untuk siapa barang tersebut di produksi; atau bagaimana barang-barang tersebut di bagikan di antara warga masyarakat? jawaban atas permasalahan yang ketiga ini pakar ekonomi kapitalis menjawabnya dengan pembahasan teori harga, yaitu peranan harga dalam menentukan produksi-komsumsidistribusi (Boediono, 1993)

Meskipun jawaban permasalahan di atas pada akhirnya harus berbenturan dengan tingkat permintaan konsumen, di mana tingkat permintaan konsumen dipengaruhi oleh banyak faktor, sehingga tingkat produksi secara riil bukanlah produksi sebanyak-banyaknya karena dapat mengakibatkan inefisiensi ekonomi dan ketidak seimbangan pasar (market disequilibrium) akan tetapi philosopi pemecahan masalah (problem solving) ekonomi dengan cara seperti ini menentukan bagaimana sistem ekonomi kapitalis melihat hakekat permasalahan ekonomi. Dengan cara pandang seperti ini, maka bagi sistem ekonomi kapitalis, solusi ekonomi yang harus ditempuh secara mikro adalah peningkatan produksi sebanyak-banyaknya, dan secara makro mengejar pertumbuhan ekonomi setinggi-tingginya.

b. Pandangan tentang nilai barang

Dalam sistem ekonomi kapitalis, nilai merupakan sesuatu yang sangat penting. Karena nilai merupakan suatu sarana untuk melihat faedah atau kegunaan suatu barang dan jasa, juga untuk menentukan kemampuan produsen dan konsumen. Ada dua kategori tentang nilai barang dan jasa yaitu yang berkaitan dengan nilai kegunaan suatu barang bagi individu yang disebut nilai guna (utility value), dan yang berkaitan dengan nilai suatu barang terhadap barang lainnya disebut nilai tukar (exchange value).

c. Peranan harga dalam sistem ekonomi kapitalis.

Harga di dalam sistem ekonomi kapitalis mempunyai peranan dalam 
kegiatan produksi, kegiatan konsumsi, serta kegiatan distribusi melalui struktur harga.

1) Peranan harga dalam kegiatan produksi

Peranan harga dalam bidang produksi, harga menentukan siapa saja produsen yang boleh masuk dalam area produksi dan siapa saja yang tidak boleh masuk atau keluar dari area produksi. Struktur harga dengan sendirinya akan megatur dan menyaring produsen berdasarkan tingkat kemampuan produsen dalam menanggung biaya produksi yang meliputi biaya pengadaan barang kemudian struktur harga juga akan menyaring para produsen yang tetap bertahan di area produksi, ketika beban biaya produksi masih dapat ditanggung produsen yang mungkin disebabkan oleh masih adanya persediaan modal yang dimiliki produsen tersebut, atau karena kemampuan inovasi produsen dalam mengelola manajemen yang efisien dan kwalitas produksi yang memenuhi selera pasar, atau juga disebabkan karena produsen tersebut melakukan praktek tidak fair dengan merusak harga pasar, monopoli atau praktek-praktek curang yang membuat produsen saingannya terlempar dari area produksi. Mekanisme persaigan ekonomi seperti ini dengan menjadikan harga sebagai alat yang megendalikan produsen dalam area produksi, maka kepemilikan produksi dalam sistem ekonomi kapitalis ditentukan oleh kekuatan modal yang dimiliki para produsen, sehingga rakyat lemah yang tidak memiliki kemampuan modal akan terlempar dari area produksi dan akhirya menjadi masyarakat pinggiran (marginal society).

2) Peranan harga dalam kegiatan konsumsi

Peranan harga dalam kegiatan konsumsi, harga merupakan alat pengendali yang menentukan kemampuan konsumen dalam memenuhi berbagai kebutuhan dan keinginannya. Harga merupakan mekanisme yang mempersilahkan orang-orang mampu untuk membeli kekayaan yang mereka kehendaki dengan uang yang mereka miliki. Harga pula yang membuat hidup orang pas-pasan, atau harga merupakan mekanisme yang menentukan siapa saja orang yang berhak hidup dan siapa saja yang harus menyingkir dari kehidupan. Misalnya adalah kebijakan 
penghapusan subsidi perguruan tinggi oleh pemerintah yang mengakibatkan biaya pendidikan, terutama biaya pendidikan diperguruan tinggi favorit meningkat tajam sehingga sulit dijangkau oleh masyarakat golongan masyarakat menengah ke bawah. Kebijakan ini akhirnya menentukan siapa saja para pemuda Indonesia yang layak melanjutkan pendidikan ke perguruan tinggi, bahkan beberapa perguruan tinggi memberikan tempat istimewa bagi orang-orang kaya melalui jalur khusus, ini tentunya tidak memberikan kesempatan yang sama pada anak bangsa untuk memiliki masa depan yang layak.

3) Peranan harga dalam kegiatan distribusi

Stuktur harga sebagai titik pertemuan antara penawaran produsen dan permintaan konsumen merupakan metode distribusi dalam sistem ekonomi kapitalis. Pertemuan antara tingkat harga yang berlaku di pasar dengan keputusan konsumen untuk membeli barang dan jasa merupakan sarana penyaring mana barang yang laku dan tidak laku. Kedua keadaan tersebut memiliki konsekwensi masing-masing. Konsekwensi pertama, terhadap barang yang laku di pasaran adalah kemungkinan keuntungan yang diperoleh produsen. Pada saat produsen untung ia akan memutuskan apakah tingkat produksi (penawaran) tetap ataukah dinaikkan. Konsekwensi kedua, terhadap barang yang tidak laku di pasaran adalah kemungkinan kerugian yang dialaminya maka ia tetap melakukan produksi meskipun dengan menurunkan tingkat produksinya. Sebaliknya, ketika produsen tidak mampu lagi menanggung kerugian, maka baginya harus menghentikan produksi atau dengan kata lain menutup usahanya. Kombinasi dua konsekwensi tersebut menghasilkan atau mengubah laju produksi sebelumnya. Adapun yang dimaksud dengan laju produksi menyangkut tiga hal, yaitu barang apa saja yang diproduksi, berapa banyak diproduksi, dan untuk siapa barang tersebut diproduksi. Bagi produsen, barang yang diproduksi adalah barang dan jasa yang menghasilkan keuntungan, yakni barang yang laku di pasaran.

Dari pemaparan di atas, sudah jelas bahwa dalam sistem ekonomi kapitalis memiliki kelebihan dan kekurangan yang masing-masing dapat dijelaskan. 
3. Kelebihan sistem ekonomi kapitalis sebagai berikut yang dirilis oleh Amazine.coOnline Popular Knowledge Tahun 2017 adalah sebagai berikut:

a. Kapitalisme mendorong pertumbuhan ekonomi dengan memfasilitasi kompetisi terbuka di pasar.

b. Sistem ini menyediakan individu kesempatan lebih baik untuk meningkatkan pendapatan mereka dan dengan demikian mencapai pertumbuhan ekonomi.

c. Hasil dari kapitalisme adalah sistem ekonomi yang terdesentralisasi. Faktor ini dianggap sebagai salah satu kelebihan terbesar kapitalisme.

d. Dalam perekonomian yang terdesentralisasi, individu memiliki lebih banyak pilihan dalam bisnis.

e. Mereka terpapar dengan kompetisi dan harus menghadapi tantangan yang berbeda serta dituntut menemukan solusi untuk unggul dalam kompetisi.

f. Kerja keras amat dihargai dalam ekonomi kapitalis. Pengusaha yang memiliki kinerja baik dan mampu terus berinovasi akan memenangkan persaingan.

g. Kapitalisme membentuk ekonomi dimana konsumen mengatur pasar. Banyak yang menganggap ini sebagai salah satu kekuatan terbesar ekonomi kapitalis. h. Sebuah pasar yang kompetitif akan merangsang inovasi dan mendorong munculnya bermacam produk dan layanan. Hal ini membuat konsumen memiliki lebih banyak pilihan serta mendorong orang untuk mencapai kebebasan finansial.

4. Kekurangan sistem ekonomi kapitalis yang dirilis oleh Amazine.co-Online Popular Knowledge Tahun 2017 adalah sebagai berikut:

a. ekonomi kapitalis dapat menimbulkan persaingan tidak sehat.

b. Kapitalisme membuat ekonomi yang berorientasi pada uang. Perusahaan bisnis akan melihat ekonomi dengan titik pandang materialistik.

c. Profit dipandang menjadi tujuan bisnis utama dengan raksasa bisnis mengambil alih perusahaan-perusahaan kecil.

d. Tenaga kerja juga dikompensasi dengan tujuan tunggal agar memiliki produktivitas lebih tinggi.

e. Sebagian ekonom percaya bahwa kapitalisme memicu penipisan sumber daya alam karena dieksploitasi untuk menjaga pertumbuhan ekonomi yang berkesinambungan.

f. Kapitalisme juga diyakini menyebabkan distribusi kekayaan yang tidak adil dengan kekayaan dan kekuasaan hanya dikuasai oleh segelintir orang. 


\section{Sistem Ekonomi Sosialis}

Sistem ekonomi ini merupakan bentuk resistensi dari sistem ekonomi sebelumnya yaitu sistem ekonomi kapitalis. Karena sistem ekonomi kapitalis dituding menjadi penyebab tidak tercapainya suatu kesejahteraan masyarakat yang merata. Sistem ekonomi sosialis merupakan kebalikan dari sistem ekonomi kapitalis, yang mana menyerahkan segala siklus ekonomi sepenuhnya kepada mekanisme pasar yang ada. Sedangkan untuk sistem ekonomi sosialis, di mana pemerintah sangat memiliki peran sangat besar di dalam mengelola roda perekonomian dari hulu hingga hilir dalam rantai perekonomian di masyarakat (Dani, 2017)

Sistem ekonomi sosialis bukan berarti tidak memberikan kebebasan individu dalam kegiatan ekonomi, individu tetap diberikan kebebasan dalam melakukan aktivitas ekonomi tetapi sangat terbatas sekali, serta dengan adanya campur tangan pemerintah yang sangat besar. Pemerintah melakukan campur tangan demi terwujudnya kemakmuran masyarakat bersama, tetapi di sisi lain kepemilikan individu yang dibatasi menyebabkan kreativitas individu menurun karena semangat untuk berkarya di bayangbayangi oleh pemerintah untuk kemakmuran bersama. Karena sistem ekonomi sosialis ini memiliki pandangan bahwa suatu kemakmuran pribadi atau individu hanya dapat terwujud jika berlandaskan kemakmuran JURNAL ILMIAH EKONOMI ISLAM VOL. 01 NO. 03, November 2015 secara bersama-sama. Sehingga konsekuensi yang harus dipertaruhkan ialah penguasaan dan kepemilikan atas aset-aset ekonomi maupun terhadap faktor-faktor produksi yang ada sebagian besarnya adalah kepemilikan untuk sosial.

1. Ciri-ciri sistem ekonomi sosialis

a. Lebih mengutamakan kebersamaan atau kolektivitas.

b. Pemerintah memiliki peran sangat besar

c. Sifat manusia dalam sistem ini ditentukan oleh pola produksi

d. Hak milik individu tidak diakui

2. Prinsip dasar sistem ekonomi sosialis menurut Caporaso (2008), adalah sebagai berikut:

a. Pemilikan harta oleh negara seluruh bentuk produksi dan sumber pendapatan menjadi milik masyarakat secara keseluruhan. Hak individu untuk memiliki harta atau memanfaatkan produksi tidak diperbolehkan.

b. Kesamaan ekonomi sistem ekonomi sosialis menyatakan, (walaupun sulit ditemui disemua negara komunis) bahwa hak-hak individu dalam suatu bidang ekonomi ditentukan oleh prinsip kesamaan. Setiap individu disediakan kebutuhan hidup menurut keperluan masing-masing.

c. Keseluruhan negara diletakkan di bawah peraturan kaum buruh, yang mengambil 
alih semua aturan produksi dan distribusi.

3. Kelebihan sistem ekonomi sosialis

a. Semua kegiatan ekonomi dikendalikan oleh pemerintah, sehingga pemerintah mudah melakukan control atau pengawasan.

b. Tidak ada kesenjangan ekonomi yang mencolok di antara anggota masyarakat.

c. Pemerintah mudah dalam mengatur dan melakukan pembentukan harga pasar atas barang dan jasa.

4. Kekurangan sistem ekonomi sosialis

a. Melemahkan bahkan mematikan inisiatif dan kreativitas individu.

b. Seringnya terjadi prakteik monopoli yang merugikan masyarakat.

c. Masyarakat tidak memiliki kebebasan di dalam memiliki sumber-sumber daya yang ada.

\section{Metodologi Penelitian}

Jenis penelitian ini merupakan penelitian kualitatif dengan menggunakan metode studi pustaka sebagai metodologi penyelesaiannya. Sehingga konsep ekonomi Islam yang diharapkan dapat terbangun melalui teori-teori yang sudah ada sebelumnya.

\section{Konsep Ekonomi Islam Jalan Tengah}

Ekonomi Islam menurut Manan (1992), adalah ilmu pengetahuan sosial yang mempelajarai ilmu ekonomi rakyat yang diilhami oleh nilai-nilai Islam. Pengertian ekonomi Islam yang lain dikemukakan oleh Halidai, ekonomi islam merupakan kumpulan dasar-dasar umum ekonomi yang disimpulkan dari al-Qur'an dan sunnah yang ada hubungannya dengan permasalahanpermasalahan ekonomi (Ali, 1988).

Beberapa tahun terakhir, tidak hanya di Indonesia bahkan dunia dikejutkan dengan berbagai demonstrasi yang marak terjadi di negara-negara Eropa. Dan yang menjadi menarik adalah, gejolak demo tersebut justru terjadi di negara yang menerapkan sistem kapitalis, kaum pekerja mempertanyakan moralitas para kapitalis dalam krisis ekonomi yang sedang melanda Eropa. Serangan yang lebih spesifik ditujukan kepada para pengejar kekayaan di Wall Street yang dianggap menjadi biang keladi dari seluruh masalah. Tercatat sejak krisis Amerika tahun 2008 hingga krisis Eropa yang terjadi saat ini telah memberikan goncangan yang hebat pada sistem kapitalis. Cara kerja sistem kapitalisme di dasarkan pada tiga pilar, yakni kebebasan individu, pasar bebas dan minimalisasi peran negara. Kapitalisme adalah sistem yang absurd, sistem yang unsur-unsurnya saling membutuhkan dan melengkapi, tetapi cara kerjanya didasarkan pada pencarian keuntungan pribadi dan persaingan. Dalam mengejar keuntungan, kaum kapitalis menggunakan beberapa cara, seperti memperpanjang jam kerja, mengurangi upah 
atau meningkatkan produktivitas. Dari ketiga cara tersebut yang paling mudah dilakukan adalah dengan meningkatkan produktivitas melalui mekanisasi, di mana jumlah alat produksi lebih banyak daripada jumlah tenaga kerja. Pada poin ini pula, fenomena neoliberal seperti sistem kerja kontrak menjadi pilihan perusahaan untuk menekan upah. Dengan begitu, buruh akan sulit mencapai hidup sejahtera, dan komunitas-komunitas adat makin terpinggirkan.

Di sisi lain, alam disedot habis-habisan dalam volume yang sangat besar agar kinerja keuangan tampak menakjubkan. Politik kekuasaan manerima kontribusi terbesar. Uang itu dipakai untuk menutup mulut politisi dan pembuat kebijakan. Sementara para politisinya membisniskan kekuasaan. Sebagian kecil dana lainnya lari ke agency-agency komunikasi periklanan untuk memoles citra bahwa mereka patuh hukum, membangun green ecosystem, dan seterusnya. Bila pertumbuhan ekonomi suatu negara kalah cepat dengan pertumbuhan gap kaya-miskin, dan pemerataan ekonomi gagal ditegakkan, maka di situlah muncul bahwa signal virus kapitalisme yang berbahaya telah mewabah. Sungguh tragis, Sektor Kesatu (APBN) telah dikuasai para politisi korup dan terbelenggu birokrasi yang kusut, Sektor Kedua dikuasai para kapitalis yang menguasai Wall Street dan pasar dengan mengeruk kekayaan sebesarbesarnya. Ini berarti Sektor Pertama dan
Sektor Kedua telah bersekutu, mengeruk kekayaan rakyat yang berbahaya bagi kesejahteraan dan kedamaian abadi. Sangat wajar jika para penggerak ekonomi baru-baru ini mempertanyakan apakah kapitalisme masih menjadi model yang tepat untuk mengelola ekonomi. Begitu pula dengan sistem ekonomi sosialis yang yang kecenderungannya semua sumber daya dikuasai oleh pemerintah, mengabaikan hak-hak kepemilikan individu, yang tentu pula melanggar hak-hak individu itu sendiri. Sehingga konsekuensi yang harus dipertaruhkan ialah penguasaan dan kepemilikan atas aset-aset ekonomi maupun terhadap faktor-faktor produksi yang ada sebagian besarnya adalah kepemilikan untuk sosial.

Oleh karenanya membangun konsep ekonomi jalan tengah akan menjadi jalan keluar yang perlu dikonsepkan terlebih dahulu, yaitu melalui konsep sistem ekonomi Islam yang diharapkan dapat mengambil kelebihankelebihan dari kedua sistem tersebut, serta meniadakan kelemahan-kelemahan dari keduanya.

\section{Ekonomi Jalan Tengah}

Sistem ekonomi jalan tengah merupakan gabungan dari dua bentuk sistem ekonomi sebelumnya, yaitu sistem ekonomi kapitalisme dan sosialisme. Usaha penyatuan ini dilakukan untuk mengambil sisi yang positif dan dinamis dari keduanya. Sistem ini hendak dibangun dengan usaha untuk 
meninggalkan unsur-unsur lemah dari dua bentuk sistem ekonomi politik tersebut.

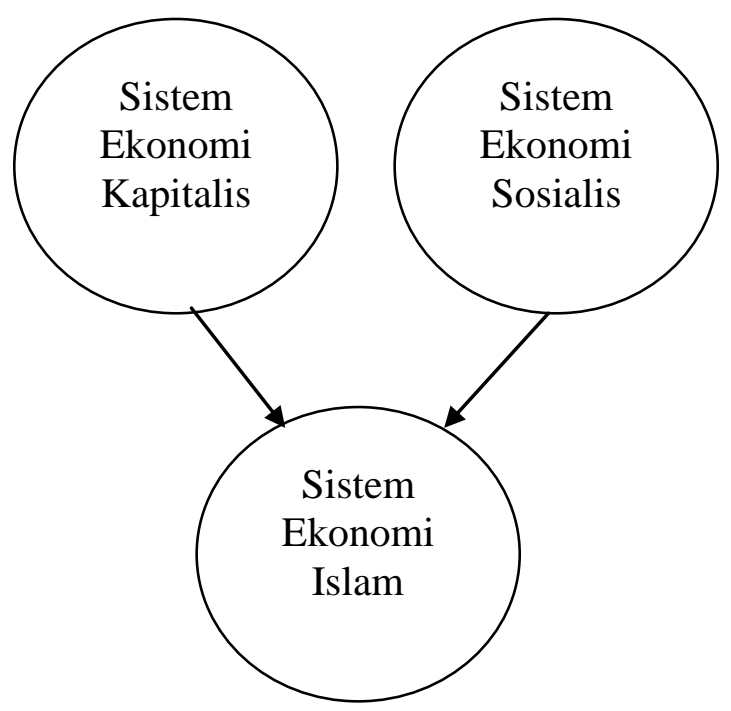

Menurut Prakasa (2011), pertentangan sejarah yang keras dan bahkan tidak harmonis dari kapitalisme dan sosialisme telah menstimulasi pemikir-pemikir untuk mencari bangun ekonomi dengan ciri dasar, yang merupakan gabungan unsur-unsur terbaik dari keduanya. Sebenarnya sistem ekonomi ini dapat saja menghilangkan konotasi perpaduan antara dua sistem ekonomi di atas karena sistem ekonomi jalan tengah dapat signifikan dalam khasnya tersendiri. Sistem menggerakkan elemen-elemen dinamis, yang sebelumnya memang dimiliki oleh masingmasing sistem ekonomi. Seperti yang dikatakan oleh Hegel bahwa perbaikan dan perkembangan pemikiran akan mencapai suatu bentuk terbaik melalui proses dialektik menuju suatu sintesa (teori dialektika). Proses ini merupakan perpanduan dari thesa dengan antithesa dalam keharmonisan dan menuju ke arah kedinamisan. Negara sedang JUFIVAL ILIVIIAT ENUIVUIVII IOLAIVI vUL. U I IVU. UJ, IvUveIIIUUer 2015 berkembang beranggapan akan mampu mengejar ketertinggalannya dengan banyak tidak mencontoh bentuk ektrim sistem ekonomi tersebut, melainkan menyerap unsur-unsur dinamis dari keduanya. Salah satu pemikiran Hegel ini menarik untuk disimak adalah dasar pemikiran mengapa muncul sistem ekonomi campuran sebagai alternatif dari sistem yang bertentangan. Jika hal itu terjadi, maka keduanya memiliki kelemahan mendasar sehingga cara terbaik adalah menggabungkannya untuk mengejar ketertinggalan negara-negara sedang berkembang. Sistem ekonomi jalan tengah merupakan perpaduan dari sitem kapitalisme dan Marxisme. Di China sistem ini disebut sebagai ekonomi pasar sosialis. Motif mencari keuntungan adalah unsur penting di dalam kegiatan ekonomi dan produksi, tetapi bukan segalanya sebagaimana ditekankan di dalam sistem ekonomi kapitalisme. Tanpa motif keuntungan tidak akan ada usaha dan pertumbuhan ekonomi akan menjadi lamban bila motif ditekan dan dimatikan seperti di negara komunis. Sistem ekonomi campuran tetap berbasis pada prinsip pasar, yang terkendali oleh aturan pemerintah dan kontrol masyarakat (Prakasa, 2011).

Selama ini ekonomi Islam hanya berkutat masalah keuangan saja, padahal dalam sistem ekonomi harusnya sistem ekonomi Islam menangani seluruh elemen dan permasalahan ekonomi masyarakat yang di antaranya modal keuangan itu 
sendiri, produksi, distribusi, konsumsi, industri, perdagangan, buruh, sumber daya alam, manajemen, dan kesejahteraan menjadi tanggung jawab ekonomi islam yang harus diselesaikan (Asy'arie, Disampaikan dalam Focused Group Discussion Matakuliah Sejarah Pemikiran Ekonomi Islam, Pascasarjana UIN Sunan Kalijaga, Kamis, 15 Desember 2016).

2. Tantangan sistem ekonomi Islam

Sampai saat ini yang seharusnya sistem ekonomi Islam lebih identik dengan pemerataan kesejahteraan serta keadilan, namun kenyataannya justru berkebalikan. Ekonomi Islam dihadapkan pada dua hal yang menjadi pekerjaan rumah yang sangat besar yaitu "kemiskinan dan kebodohan". Kemiskinan menjadi tantangan yang sangat berat bagi setiap negara dalam melakukan penyelesaiannya. Karena hampir setiap negara menjadikan program pengentasan kemiskinan menjadi program utama dalam kegiatan ekonomi. Termasuk Islam sendiri menganjurkan agar menghindarkan diri dari kemiskinan sebagaimana sabda Rasulullah SAW berikut ini:

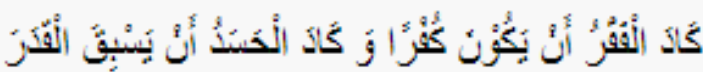

"Hampir-hampir saja kefakiran akan menjadi kekufuran dan hampir saja hasad mendahului takdir."

Karena kefakiran satu sisi terkadang mendorong seseorang untuk senantiasa melakukan tindakan-tindakan yang tak JUKIVAL ILIVIIAH EKUINUIVII ISLAIVI VUL. UI INU. US, INovemper 2015 dibenarkan baik oleh agama maupun oleh hukum negara. Sehingga dikhawatirkan pula kefakiran juga dapat memaksa seseorang untuk melakukan berbagai tindakan yang melanggar berbagai norma; seperti mencopet, mencuri, merampok, melacur, dan menipu dan lain-lain. Karenanya, tidak dapat disalahkan seandainya ada ungkapan atau istilah bahwa kefakiran atau kemiskinan dapat mendekatkan seseorang kepada kekufuran.

Kenyataan permasalahan selain kemiskinan adalah kebodohan, padahal masyarakat akan sejahtera terhindar dari kemiskinan, logika seharusnya masyarakatnya cerdas. Dengan kata lain kebodohan sejalan dengan kemiskinan. Sehingga kebodohan ini sebagai sumber daya yang berupa sumber daya manusia yang harus diatasi terlebih dahulu, agar nantinya masalah kemiskinan juga dapat terselesaikan.

Sebuah hasil penelitian melalui survey yang dipublikasikan oleh Direktur Riset GlobeScan yaitu Sam Mountford melalui BBC pada tanggal 17 Januari tahun 2012 menempatkan dalam hal ini adalah kemiskinan kemiskinan sebagai masalah atau persoalan yang dianggap paling serius serta krusial yang dihadapi oleh seluruh masyarakat di dunia jika dibandingkan dengan masalah-masalah yang lain, seperti terorisme, perubahan iklim, dan perang. 
Hasil survei itu di dapat prosentasi besaran adalah sebagai berikut; kemiskinan ekstrim $71 \%$, lingkungan $64 \%$, meningkatnya harga pangan dan energy $63 \%$, terorisme dan hak asasi manusia serta penyebaran penyakit $59 \%$, malah ekonomi dunia 58\%, perang $57 \%$. Penelitian ini dilakukan terhadap 25 ribu orang lebih dari 23 negara (http://www.waspada.co.id/kemiskinanjadi-masalah-terbesar-dunia)

Dalam Konteks bangsa Indonesia, Salah satu permasalahan serta problematika mendasar yang saat ini tengah dihadapi problematika berupa problematika kemiskinan. Menurut data yang diperoleh dari Bank Dunia 1978, dari seluruh penduduk Indonesia yang waktu itu berjumlah sekitar 132 juta, dimana 72 juta jiwa dalam keadaan miskin dan $55 \%$ bahkan jauh berada di bawah garis kemiskinan, tentunya hal ini sangat mengejutkan, karena negara yang notabenya sumber daya alamnya sangat melimpah ternyata mayoritas masyarakatnya masih miskin, bahkan di bawah garis kemiskinan. Menurut data statistika dari tahun 1976 sampai dengan tahun 2000, angka kemiskinan yang ada di Indonesia selalu berubah-ubah, namun dari perubahan data tersebut masih tetap tergolong sangat besar dan sangat mengkhawatirkan. Jumlah masyarakat atau penduduk miskin pada tahun 1998 adalah
49,5 juta orang atau kalau diprosentase sebesar $24,2 \%$ dari total seluruh jumlah penduduk Indonesia, dengan rincian sebagai berikut: dimana 31,9 juta penduduk berada di pedesaan $(25,7 \%)$, sedangkan 17,6 juta penduduk berada diperkotaan (21,9\%). Data yang dibuat terakhir oleh Badan Pusat Statistik atau BPS menunjukkan bahwa jumlah penduduk miskin mendekati sebesar 50 juta jiwa atau orang. Dari jumlah di atas 32,7 juta jiwa atau 64,4 tinggal atau berada di pedesaan (Siahaan, 2004: 83-84). Kenyataan ini turut berimbas dan berpengaruh pada angka pengangguran yang juga sangat tinggi, yaitu sekitar 28 juta jiwa, atau jika diprosentase sebesar 12,7 persen dari total penduduk (Didin Hafidhuddin, 2006).

Oleh karena itu, dengan menyatukan kelebihan (yang tidak melanggar prinsipprinsip syariah) dari sistem ekonomi kapitalis dan sistem ekonomi sosialis, tentunya kemiskinan dan kebodohan suatu masyarakat di sebuah negara atau bangsa dapat diminimalisir atau dihilangkan sedikit demi sedikit secara berkesinambungan, dengan tanpa melanggar prinsip-prinsip syariah yang telah ditentukan oleh Islam. Hal itu akan dapat terwujud dan dapat diterapkan dengan cara memadukan semua elemen masyarakat suatu negara dari bawah sampai atas untuk berubah terutama dari 
diri sendiri, keluarga, masyarakat, dan seluruh masyarakat dalam sebuah negara.

3. Politik dan ekonomi

Setiap negara dalam bentuk apapun yang berdaulat dan memiliki pemerintahan dalam upayanya untuk mensejahterakan rakyat dan masyarakatnya harus mempunyai suatu identitas kebangsaan. Dalam upaya peningkatan kesejahteraan dan pemerataan umumnya dilakukan melalui upaya-upaya atau usaha-usaha peningkatan pertumbuhan ekonomi sedangkan upaya untuk menjamin dalam terpeliharanya identitas bangsa dan negara umumnya dilakukan melalui berbagai kegiatan dan tahapan proses pembangunan yang berkelanjutan.

Dalam permasalahan hubungan ini, pertumbuhan ekonomi suatu bangsa dan negara merupakan upaya peningkatan kegiatan ekonomi dalam berbagai suatu sistem ekonomi tertentu, sedangkan pembangunan ekonomi merupakan upaya pengembangan sistem ekonomi itu sendiri. Tanpa adanya kesepakatan tentang sistem ekonomi yang dianut maka dapat lebih terbuka kemungkinan terjadinya perselisihan pendapat mengenai kebijakan ekonomi yang patut ditempuh dalam mengatasi berbagai persoalan-persoalan ekonomi mendasar yang dihadapi suatu bangsa dan negara. Meskipun dalam berbagai proses dalam pembentukan public policy selalu terdapat suatu public debate, tetapi jika telah ada kesepakatan atau permusyawatan tentang suatu sistem ekonomi maka akan diredam terjadinya perselisihan pendapat dari suatu ekstrim ke ekstrim lain yang selain dapat memperlamban proses pengambilan keputusan juga akan menciptakan iklim ketidakpastian bagi dunia bisnis dan akhirnya menganggu stabilitas politik dan ekonomi itu sendiri.

Oleh karena itu, dalam hal ini suatu kebijakan politik dan sistem ekonomi merupakan dua bagian yang tidak mungkin dapat dipisahkan antara satu sama lain. Karena suatu tindakan maupun suatu kebijakan politik dalam perkancahan negara dan suatu bangsa sangat menentukan arah dan tindak lanjut dari sistem perekonomian yang dianutnya tersebut, sehingga selalu seiring dan seirama dalam pelaksanaan atau aplikasinya.

Hal yang justru mengherankan sekarang ini banyak orang ingin membangun sistem ekonomi berdasarkan khilafah, padahal sistem ekonomi Islam sebagai jalan tengah sampai hari ini belum terealisasi. Pendapat Asy'arie, karena kebanyakan orang berfikir bahwa ekonomi Islam identik dengan ekonomi timur tengah, atau ekonomi masa Rasul dan Sahabat, padahal tidak begitu sesungguhnya. Sehingga perlu berfikir 
secara realistis bahwa perlu membangun konsep terlebih dahulu. Konsep itu tentunya tidak lepas dari yang namanya politik dan ekonomi. Sehingga dalam membangun suatu sistem ekonomi, politik tidak dapat dipisahkan di dalamnya.

Berkaca dari sejarah sampai saat ini, bahwa dua hal tersebut saling berkesinambungan. Artinya politik tidak dapat terpisahkan dari ekonomi, maupun sebaliknya. Sehingga ketika ingin membangun ekonomi jalan tengah terlebih dahulu mensinergikan ekonomi Islam yang dibangun dari politik dan ekonomi itu sendiri, sehingga peran negara sangatlah penting di dalam membangun sebuah sistem ekonomi agar dapat berhasil sesuai yang diharapkan.

\section{Kesimpulan}

Dari beberapa uraian di atas dapat disimpulkan bahwa sistem ekonomi kapitalis maupun sistem ekonomi sosialis selama ini tidak mampu mewujudkan kesejahteraan dan keadilan baik untuk individu sebagai bagian dari negara (sistem ekonomi sosialis) maupun masyarakat pada umumnya atau kaum buruh ( sistem ekonomi kapitalis). Sehingga mau tidak mau perlu adanya terobosan dengan membangun konsep sistem ekonomi Islam sebagai jalan tengah dengan menggabungkan dari dua bentuk sistem ekonomi sebelumnya, yaitu sistem ekonomi kapitalisme dan sosialisme. Usaha penyatuan ini dilakukan untuk mengambil sisi yang positif dan dinamis dari keduanya.

Tantangan besar ekonomi Islam adalah dihadapkan pada dua hal yang menjadi pekerjaan rumah yang sangat besar yaitu "kemiskinan dan kebodohan". Membangun konsep sistem ekonomi Islam tidak dapat dipisahkan antara politik dan ekonomi. Keduanya harus saling bersinergi agar terwujud sistem ekonomi yang berkeadilan menuju kesejahteraan masyarakat.

\section{Daftar Pustaka}

Agustiati, Sistem Ekonomi Kapitalisme, Jurnal Academica, Volume 1 Nomor. 2, Palu: Universitas Tadulako, 2009

Amazine.co-Online Popular Knowledge. Kelebihan dan Kekurangan Sistem Ekonomi Kapitalis. 2017

Asy'arie, Musa, Prof. Dr., Disampaikan dalam Focused Group Discussion Matakuliah Sejarah Pemikiran Ekonomi Islam, Pascasarjana (S3 Ekonomi Islam) UIN Sunan Kalijaga, Kamis, 15 Desember 2016

Boediono, Ekonomi Makro, Seri Sinopsis Pengantar Ilmu EkonomiNo. 2, Edisi, Yogyakarta: BPFE, 1993

Caporaso, A. James, Teori Teori Ekonomi Politik, Yogyakarta: Pustaka Pelajar, 2008

Chaudhry, Muhammad Sharif, Sistem Ekonomi Islam, Prinsip Dasar, Jakarta: Kencana, 2012

Didin Hafidhuddin, Zakat Sebagai Tiang Utama ekonomi Syariah, Makalah disampaikan pada acara Seminar Bulanan Masyarakat ekonomi Syariah, (Jakarta, Aula bank Mandiri Tower, 2006) 
http://www.waspada.co.id/kemiskinan-jadimasalah-terbesar-dunia. diakses pada tanggal 21 Agustus 2015

Manan, M. A., Teori dan Praktik Ekonomi Islam, 1992
Siahaan, N.H.T., Hukum Lingkungan dan EkologiPembangunan, (Jakarta:Erlangga , 2004), hal. 83-84

Winardi, Ilmu Ekonomi (Aspek-Aspek Sejarahnya), (Bandung: PT Citra Aditya Bakti), 1990 